\title{
Effects of Board of Directors' Characteristics on the Quality of Accounting Information in Brazil
}

\author{
Luciana Holtz \\ Assistant Professor, Department of Economics and Finance, Federal University of Juiz de Fora \\ E-mail: Luciana.holtz@ufj.edu.br
}

\author{
Alfredo Sarlo Neto \\ Adjunct Professor, Department of Accounting Sciences, Federal University of Espírito Santo \\ E-mail: sarloneto̊@ccje.ufes.br \\ Received on 10/28/2013 - Desk acceptance on 11/14/2013 - $3^{\text {rd }}$ version accepted on 07/23/2014
}

\begin{abstract}
One of the board of directors' responsibilities is to monitor the quality of information disclosed in financial reports. The board's structural and compositional characteristics can affect the quality of reported accounting information. The aim of this study was to investigate the effects of the board's structural and compositional characteristics on the quality of accounting information of companies listed on the Brazilian Securities, Commodities, and Futures Exchange (Bolsa de Mercadorias e Futuros - BM\&FBovespa). Specifically, the characteristics studied were the size and independence of the board of directors and separation of the roles of chairman and executive director. Accounting information relevance and earnings informativeness were used as proxies for the quality of accounting information. The sample included non-financial companies listed on the BM\&FBovespa with annual stock market liquidity higher than 0.001, covering the period from 2008-2011. Data were collected from the Economática database and directly from companies' annual reports and reference forms available on the Securities Commission (Comissão de Valores Mobiliários - CVM) or BM\&FBovespawebsites. Data analysis was undertaken using the multiple regression technique for calculating the models of accounting information relevance and earnings informativeness. The results reveal that, for companies that trade stocks on the BM\&FBovespa in the Brazilian market, the characteristics of board independence and separation of the roles of chairman and executive director positively influence the quality of reported accounting information, specifically regarding the relevance of equity. Earnings informativeness is positively affected by board independence and negatively affected by larger board size (more than nine members). Overall, the results corroborate international studies such as those of Vafeas (2000), Firth, Fung, and Rui (2007), Ahmed, Hossain, and Adams (2006) and Dimitropoulos and Asteriou (2010), especially regarding board independence. The study showsthat stronger governance structures have a positive effect on the quality of reported accounting information.
\end{abstract}

Keywords: Earnings informativeness; accounting information relevance; characteristics of the board of directors. 


\section{INTRODUCTION}

Studies on corporate governance have received growing academic and business attention, and according to Gillan (2006), the number of studies has increased dramatically in the last decade. Among these studies, discussions on board composition have examined issues related to the size of the board, the executive director's participation on the board, and the proportion of board independence (Adams, Hermalin, \&Weisbach, 2010; Anderson, Mansi, \&Reeb, 2004).

According to Jensen (1993), the board is responsible for a company's internal control systems and has the ultimate responsibility for the operation of the company. Boards define the rules for the chief executive officer (CEO/ executive director) regarding hiring, firing, and compensation plans and provide high-level advice. Fama and Jensen (1983) attribute to boards the functions of ratification of project proposals suggested by management and monitoring the implementation of these projects.

For Vafeas (2000), boards are responsible for monitoring the quality of information contained in financial reports because managers often have their own interests and incentives with regard to managing earnings and potentially misleading stock holders.

Agency conflicts and information asymmetry can be observed in the activities of modern organizations. Lopes (2008, p.172) argues, "[...] One cannot aspire to conduct a serious study of modern organizations without consideration of these two factors," and notes that accounting is a way to reduce information asymmetry.

Studies on the characteristics of corporate governance, in particular those related to the board of directors and the quality of accounting information, are already available in the international literature, including, for example, the studies by Vafeas (2000), Firth et al. (2007), Ahmed et al. (2006), Dimitropoulos and Asteriou (2010), Abdoli and Royaee (2012), Habib and Azim (2008), Alkdai and Hanefah (2012), and Alves (2011), among others.

In Brazil, the research has generally addressed broad characteristics of corporate governance and quality of accounting information, such as the studies by Lopes and Walker (2008) and Antunes, Teixeira, Costa, and Nossa (2009). Because the board's structural and compositional characteristics can affect the quality of reported financial information, and empirical evidence on these effects in Brazil is scarce, this study aims to investigate the following question: What is the effect of the board's characteristics on the quality of financial information of companies listed on the BM\&FBovespa?

In line with the proposed research problem, the aim of this study is to investigate the effects of board size and independence as well as of the separation of the chairman and executive director's roles on accounting information relevance and earnings informativeness of companies listed on the BM\&FBovespa.

According to Lopes and Walker (2008), most studies linking corporate governance to financial information use data from the United States and United Kingdom, where the level of investor protection is already high. These authors argue that studies of this relationship in companies from institutional environments that are considered poor, such as Brazil, are important.

The results of this research will provide a new perspective on the quality of accounting information in interaction with other corporate governance mechanisms, filling a gap in the national literature and contributing to the more developed international literature on the subject. The choice of accounting information relevance and earnings informativeness as proxies for the quality of accounting information is justified because these parameters are used internationally in studies investigating the interaction between corporate governance and the quality of accounting information, as observed by Vafeas (2000), Firth et al. (2007), Habib and Azim (2008), and Alkdai and Hanefah (2012).

Our analysis of the effect of the board's characteristics on the quality of accounting information disclosed by companies can contribute to a better understanding of both areas and assist in understanding the role of the board of directors within companies attempting to mitigate conflicts of interest. It may also assist corporations in forming their boards by using structures that convey greater credibility to the investor. Furthermore, it is hoped that the results of this study will contribute to the development of advisors, investors, creditors, and scholars.

The study is divided into five sections, including this introduction. The second section covers the theoretical framework and the development of the hypotheses. The third section addresses the research methodology, while the analyses and a discussion of the results are presented in the fourth section. The concluding remarks and suggestions for future studies are reported in the fifth section.

\section{THEORETICAL FRAMEWORK}

\subsection{Agency Theory.}

Jensen and Meckling (1976) report that the presence of a separation between ownership and management in most large companies allows administrators not to assume the financial burdens of their decisions. The separation of ownership and control of a company appears as a triggering factor for the problem of agency.

In cases where there are controlling stockholders and less liquid secondary markets, Bratton and Mccahery (1999) suggest the use of internal management control mechanisms as an alternative for the protection of minority stockholders. The board of directors is a valid op- 
tion in this regard. For La Porta, Lopez-De-Silanes, Shleifer, and Vishny (2000), investor protection is crucial because in many countries expropriation of minority stockholders and creditors by controlling stockholders is extensive.

In reviewing the accounting research related to corporate governance, Bushman and Smith (2001) show that accounting can be used as a control mechanism through which investors and stockholders can monitor managers' actions. The authors also claim that accounting plays an important role in contracts established with managers because it provides variables for defining the basis of their benefit plans (incentives).

"Agency conflict is exacerbated by the problem of information asymmetry" (Lopes, 2008, p.182). According to the author, accounting can contribute to a company's corporate governance mechanisms by providing useful information to decision makers and therefore reducing information asymmetry and the impact of agency conflicts.

\subsection{Boards of Directors.}

Hermalin and Weisbach (2003) argue that boards do not exist only to satisfy legal requirements because if so, their composition would also be legally demanded, whereas in practice, different compositions are observed. The authors argue that if board composition were merely the result of laws, somewhere in the world, there would be a lobby to eliminate any requirements.

For Hermalin and Weisbach (2003), boards are a market solution that helps to mitigate the agency proble$\mathrm{ms}$ that plague any large organization. Whatever their virtues or problems, boards of directors are part of the market solution to problems with contracts.

According to Alves (2011), the ability of managers to manage an organization's reported results is limited by the effectiveness of internal controls, including that of boards. Boards are responsible for monitoring the quality of information contained in financial statements and thus controlling the behavior of managers to ensure that their actions are aligned with the interests of stakeholders.

Authors such as Anderson, Mansi, and Reeb (2004) argue that boards of directors are responsible for monitoring, evaluating, and disciplining the management of a company, and oversight of financial reporting is one of the most important responsibilities of the board from the point of view of creditors. Beekes, Pope, and Young (2004) believe that financial reports represent a particularly clear example of an activity in which the interests of managers and stockholders may not be perfectly aligned.

In Brazil, boards originate from a legal provision and consist of a deliberative body composed of at least three members, as required by art. 140 of the Corporations Act - Law 6,404 of December 15, 1976 and amendments. According to article 142 of this law, boards have the role of monitoring management activities.

\subsection{Quality of Accounting Information.}

Due to capital market growth since the 1960s, especially in North America, and the development of financial theories, accounting has expanded its field of research. The information contained in figures recorded through accounting has therefore been the subject of several studies under an information approach (Lopes, 2002).

The seminal studies of Ball and Brown (1968) and Beaver (1968) provide evidence that accounting information is reflected in stock prices and demonstrate the importance of accounting for investors.

However, according to Brown, He, and Teitel (2006), this reflex can be influenced by the relevance and reliability of the financial statements prepared by management. Earnings reported in financial statements are the joint responsibility of managers and auditors.

In Brazil, studies by Lopes and Walker (2008) and Antunes et al. (2009) evaluate the quality of accounting information and corporate governance. Lopes and Walker (2008) use the corporate governance index of Brazil and conclude that the quality of earnings of cross-listed Brazilian companies with good governance is similar to the quality reported for companies in developed common-law countries.

Antunes et al. (2009) investigate the impact of different levels of the BM\&FBovespa on the quality of accounting information based on a sample covering the years from 1996-2006. They conclude that in general, the different levels do not affect quality. The authors only observe a relationship with conservatism when a broader governance index is used.

By providing empirical evidence, Gabriel (2011) demonstrates that the structure of corporate governance can positively influence the quality of accounting information produced by a company and disclosed to stockholders.

According to Barth, Beaver, and Landsman (2001), accounting information is relevant when there is a significant relationship with stock price, i.e., when the information is important to investors in valuing the company and is measured in a sufficiently reliable manner to be reflected in its stock price.

The relevance model is based on the premise that the stock price (market value) is a variable that can be explained by accounting earnings under the hypothesis that current earnings contain information about future net cash flows (Kothary\& Zimmermann, 1995). According to Habib and Azim (2008), the justification for including equity in the relevance model is based on the assumption that the book value of equity is a proxy for the present value of expected normal future profitability and that it reveals a company's liquidation value.

According to Sarlo Neto (2009), informativeness is a measure of the intensity of the relationship between accounting information and stock returns and is usually represented by the association between stock price returns and accounting earnings. The stronger the relationship between stock returns and accounting earnings, the greater the earnings informativeness (Sarlo Neto, 2009). 
The central idea in accounting earnings informativeness is the use of accounting earnings by investors as useful information for adjusting their expectations. Therefore, if accounting earnings contain new information (surprises), it will cause adjustments in investors' expectations and hence to the stock price and market value of the company; otherwise, there will be no impact (Sarlo Neto, 2009).

\subsection{Studies on Quality of Accounting Information and Board Characteristics.}

This section aims to summarize the literature that jointly addresses the relationship between the quality of accounting information and the composition of boards of directors. It contains evidence of previous studies conducted in markets outside of Brazil.

Table 1 summarizes the main results of international research pertaining to the subject of the present study.
An analysis of the studies listed in Table 1 reveals international evidence that boards with fewer members are associated with a higher quality of accounting information, as noted by Vafeas (2000), Ahmed et al. (2006), and Alves (2011).

The board's greater independence is another aspect associated with a higher quality of accounting information, as observed in studies by Beekes, Pope, and Young (2004), Firth et al. (2007), Ahmed and Duellman (2007), Marra, Mazzola, and Prencipe (2009), Dimitropoulos and Asteriou (2010), and Abdoli and Royaee (2012).

The participation of the executive director as the chairman of the board of directors has also been studied internationally, and there is evidence that such participation negatively affects the quality of accounting information, as expressed in the results of studies by Lara, Osma, and Penalva (2007) and Firth et al. (2007).

Table $1 \quad$ Summary of results of major international studies

\begin{tabular}{|c|c|c|c|}
\hline Authors & Period & Country & Main results \\
\hline Vafeas (2000) & 1990-1994 & United States & $\begin{array}{l}\text { The results show that the earnings of companies with smaller boards are } \\
\text { perceived as more informative by market participants; however, no evidence } \\
\text { is found that a larger proportion of independent directors increases earnings } \\
\text { informativeness. }\end{array}$ \\
\hline Xie, Davidson, and Dadalt (2003) & $\begin{array}{l}1992,1994, \\
\text { and } 1996\end{array}$ & United States & $\begin{array}{l}\text { The authors' conclusion is that the financial expertise of members of boards and } \\
\text { committees and the activities of these groups are important factors in limiting } \\
\text { managers'results management. }\end{array}$ \\
\hline Beekes, Pope, and Young (2004) & 1993-1995 & United Kingdom & $\begin{array}{l}\text { The results show that companies with a higher proportion of external directors } \\
\text { are more likely to recognize bad news in the results in a timely manner. } \\
\text { However, companies with boards with a relatively high proportion of external } \\
\text { directors do not exhibit greater conservatism regarding the recognition of good } \\
\text { news. }\end{array}$ \\
\hline $\begin{array}{l}\text { Ahmed, Hossain, and Adams } \\
\text { (2006) }\end{array}$ & 1991-1997 & New Zealand & $\begin{array}{l}\text { The results show that earnings informativeness is negatively related to the size } \\
\text { of the board. }\end{array}$ \\
\hline Firth, Fung, and Rui (2007) & 1998-2000 & China & $\begin{array}{l}\text { Empirical results find that companies with more independent directors that } \\
\text { separate the roles of chairman and executive director have greater earnings } \\
\text { informativeness. }\end{array}$ \\
\hline Ahmed and Duellman (2007) & 1999-2001 & United States & $\begin{array}{l}\text { The results indicate that accounting conservatism is positively associated with } \\
\text { the equity participation of independent directors and negatively associated with } \\
\text { the percentage of insider directors. }\end{array}$ \\
\hline Lara, Osma, and Penalva (2007) & 1997-2002 & Spain & $\begin{array}{l}\text { Empirical evidence indicates that companies in which the executive director } \\
\text { has little influence on the functioning of the board have a higher degree of } \\
\text { accounting conservatism. }\end{array}$ \\
\hline Habib and Azim (2008) & 2001-2003 & Australia & $\begin{array}{l}\text { The results indicate that companies with strong governance structures have } \\
\text { greater accounting information relevance. }\end{array}$ \\
\hline $\begin{array}{l}\text { Marra, Mazzola, and Prencipe } \\
\text { (2011) }\end{array}$ & 2003-2006 & Italy & $\begin{array}{l}\text { The results suggest that independence of the board of directors and the } \\
\text { existence of audit committees play important and effective roles in reducing } \\
\text { earnings management after the adoption of the International Financial Reporting } \\
\text { Standards (IFRS) in the country. }\end{array}$ \\
\hline Alves (2011) & 2002-2007 & Portugal & $\begin{array}{l}\text { The results suggest that a smaller board composed mostly of non-executive } \\
\text { directors improves the quality of accounting earnings by demonstrating a } \\
\text { negative relationship with earnings management. There is evidence that a larger } \\
\text { board has a positive relationship with earnings management. }\end{array}$ \\
\hline Alkdai and Hanefah (2012) & 2007-2009 & Malaysia & $\begin{array}{l}\text { The results do not identify relationships between the size and independence } \\
\text { of the board of directors, the separation of roles, and the number of Muslim } \\
\text { directors with accounting information relevance. }\end{array}$ \\
\hline Abdoli and Royaee (2012) & $2005-2010$ & Iran & $\begin{array}{l}\text { The results indicate greater earnings informativeness in companies with a higher } \\
\text { percentage of independent directors in which the chairman is also the executive } \\
\text { director. }\end{array}$ \\
\hline
\end{tabular}


Given the general characteristics of boards as discussed by Xie, Davidson, and Dadalt (2003) and Habib and Azim (2008), it is possible to observe that the board's structure affects the quality of accounting information.

When considering the results of the studies presented in Table 1 as a whole, it is possible to observe a tendency for board composition to have an effect on the quality of accounting information. However, it is not possible to state that these effects occur in all types of markets, as shown by the results of Alkdai and Hanefah (2012), who find no empirical evidence of such effects.

It is therefore timely to investigate the Brazilian market based on the hypothesis that board characteristics affect the quality of accounting information reported to users in this market.

\subsection{Development of Study Hypotheses.}

\subsubsection{Hypotheses related to board size.}

Board efficiency involves the issue of increases in coalition costs between members and the fact that boards with more members have greater difficulty finding time to discuss and reach consensus on issues pertaining to the company's organizational structure (Firth, Fung, \&Rui, 2006).

Lipton and Lorsch (1992) suggest that one reason for the lack of meaningful dialogue on boards is their size. According to the authors, when a board has more than ten members, it becomes difficult for everyone to express their opinions and ideas in the limited time available for meetings.

According to Ahmed and Duellman (2007), larger boards can face the problem of "free riding" in the sense that the members of the board depend on each other to monitor management. Jensen (1993) believes that as the number of directors increases, the board's efficiency decreases, and internal conflicts can arise.

For Vafeas (2000), the possibility exists that boards can be considered effective when they have an intermediate number of members. In line with the views of Linpton and Lorsch (1992) and Jensen (1993), the Brazilian Institute of Corporate Governance (Instituto Brasileiro de Governança Corporativa - IBGC), in its Manual of Good Corporate Governance Practices (IBGC, 2009), recommends that boards be composed of a minimum of five members and a maximum of eleven members.

Based on these initial considerations, this study's hypotheses related to board size are as follows:

- Hypothesis 1a: Board size, in particular boards with a higher number of members, is negatively related to accounting information relevance.

- Hypothesis 1b: The informativeness of reported accounting earnings is negatively related to board size.

- Hypothesis 1c: Earnings informativeness is greater in companies that meet the IBGC's recommendations on the number of members on the board of directors.

\subsubsection{Hypotheses relating to board independence.}

Boards of directors dominated by independent directors are more effective in exercising their control function because they are less influenced by management (Fama\& Jensen, 1983). Beasley (1996) concludes that monitoring of the quality of financial reporting by independent directors reduces the likelihood of financial fraud.

For Beekes et al. (2004), insider directors are loyal to the executive director/CEO due to their interest in remaining employed by the company; the incentive for them to monitor the quality of accounting information is therefore considerably less than for independent directors.

According to Lopes and Walker (2008), the presence of an independent board of directors can be perceived by the market as a sign that a company is committed to behaving according to the basic rules of good conduct.

The hypotheses relating to board independence are as follows:

- Hypothesis 2a: Board independence is positively related to accounting information relevance.

- Hypothesis 2b: Reported accounting earnings informativeness is positively related to the percentage of board independence.

\subsubsection{Hypotheses relating to the separation of chair- man and executive director/CEO roles.}

Jensen (1993) states that when the CEO also holds the position of chairman of the board, internal control systems, such as the board of directors, may not effectively fulfill their main control functions. For Fama and Jensen (1983), it is inappropriate for the same individual to be responsible for the implementation and monitoring of decisions. According to these authors, this dual responsibility decreases the efficiency of board control.

Authors such as Yermark (1996) and Brown and Caylor (2006) obtain evidence that the market value of a company is greater when the CEO and chairman roles are occupied by different people.

The occupation of the roles of chairman and executive director by the same person can reduce the independence of the board as well as its ability to control managers effectively. One effect could be a decreased dissemination of timely and relevant information to external stakeholders (Gul \& Leung, 2004).

The hypotheses relating to the separation of the chairman and executive director/CEO roles are as follows:

- Hypothesis 3a: The separation of the roles of chairman of the board and executive director is positively related to accounting information relevance.

- Hypothesis 3b: Accounting earnings informativeness is greater in companies where there is a separation between the roles of chairman of the board and executive director/CEO. 


\section{RESEARCH METHODOLOGY}

The sample comprises active companies listed on the BM\&FBovespa for which data were available for the period from 2008-2011. The sample was selected based on annual stock market liquidity above 0.001 . This criterion was used to ensure that the sample companies had at least a minimum number of asset trades because companies with very low liquidity are less likely to possess quotations that approximate their market values, which is important for this study. Financial companies and mutual funds were excluded from the sample due to their peculiarities regarding the calculation of results and the fact that their accounting structures are not analogous to those of other companies according to Moreira, Colauto, and Amaral (2010).

The financial statement disclosure date was considered to be the record date of sending the file to the CVM, if before $5 \mathrm{pm}$, or the day after in other cases, because the closing time of the São Paulo Stock Exchange is 5pm. This parameter was specifically used in to ascertain the stock price and the value of the Bovespa index.

The boards' characteristics were obtained by consulting the annual reports (AR) for the years 2008 and 2009 and reference forms (RF) for the years 2010 and 2011. The $\mathrm{AR}$ or RF used for the collection of information regarding board characteristics was the last one sent to the CVM prior to the disclosure date of the financial statements, considering that these documents are public information available on the presentation date of the financial information of interest.

Stock prices, the value of the Bovespa, and information on the boards of directors were collected manually by company and year according to the disclosure date of the companies' financial statements.

For variables that use accounting information, the base collection date was the closure of the accounting year on December 31. Figures for the last trading day of the year, i.e., December 30, were used for market value. Data were collected using the Economática software.

The final sample is composed of 678 observations from 207 different companies belonging to 19 sectors of the economy according to the Economática classifications.

Toachieve the proposed objectives, this study used multiple regression as its main data analysis tool and employed two econometric models established in the literature: the relevance model, based on Habib and Azim (2008) and Alkdai and Hanefah (2012), and the informativeness model, based on Easton and Harris (1991) and Vafeas (2000), according to the following specifications:

Equation 1 - Relevance Model

$$
P_{i, t}=\delta_{0}+\delta_{1} A E_{i, t}+\delta_{2} E Q_{i, t}+\delta_{3} A E_{i, t} * S C_{j, i, t}+\delta_{4} E Q_{i, t} * S C_{j, i, t}+\delta_{5} I D B_{i, t}+\delta_{6} M T B_{i, t}+\delta_{7} S I Z_{i, t}+\xi_{i, t}
$$

where:

$\mathrm{P}_{\mathrm{i}, \mathrm{t}}=$ stock price of company $i$ in period $t$ divided by the stock price at $t-1$;

$\mathrm{AE}_{\mathrm{i}, \mathrm{t}}=$ accounting earnings adjusted by market value of company $i$ in period $t$;

$\mathrm{EQ}_{\mathrm{i}, \mathrm{t}}=$ equity adjusted by market value of company $i$ in period $t$;

$\mathrm{SC}_{\mathrm{i}, \mathrm{t}}=$ independent variables representing the structural and compositional characteristics of the board of directors of company $i$ in period $t$, including SB (size of the board - represented by the number of effective members as stated in the AR or RF), IND (board independence - represented by the ratio of the number of independent directors to the total number of directors in the company (\%). Independent directors are identified as those who are classified by companies as such in their AR and RF), or CCEO (separation of the roles of chairman of the board of directors and executive director/CEO - a dummy variable that assumes a value of 1 when the roles of chairman and CEO are separated. This information is obtained through analysis of the AR or RF);

$\mathrm{IDB}_{\mathrm{i}, \mathrm{t}}=$ proxy for indebtedness of the company, represented by the debt capital divided by total liabilities, used as a control variable;

$\mathrm{MTB}_{\mathrm{i}, \mathrm{t}}=$ proxy for growth opportunity, defined as the market value of assets divided by the book value of equity of the company, used as a control variable;

$\mathrm{SIZ}_{\mathrm{i}, \mathrm{t}}=$ proxy for company size, represented by the natural logarithm of market value, used as a control variable; $\xi_{\mathrm{i}, \mathrm{t}}=$ error term of company $I$ in period $t$.

The analysis rests on the $\delta_{3}$ and $\delta_{4}$ coefficients (interaction between accounting earnings or equity and the board structure variables, which are inserted into the model individually). Information relating to board characteristics is considered relevant to the market if the $\delta_{3}$ and/or $\delta_{4}$ coefficients are/is significantly different from zero.

$$
S R_{i, t}=\beta_{0}+\beta_{1} A E_{i, t}+\beta_{2} A E * S C_{j, i, t}+\beta_{3} A E^{*} N E G_{i, t}+\sum_{s=2}^{19} \phi_{s} S_{i, t}+\sum_{A=2}^{4} \delta_{A} Y_{i, t}+\xi_{i, t}
$$


where:

$\mathrm{SR}_{\mathrm{i}, \mathrm{t}}=$ measure of stock return of company $i$ in period $t(\mathrm{ab}-$ normal return - represents the excess return of the company relative to the market in a given period of time. Market return was measured using the Bovespa Index);

$\mathrm{AE}_{\mathrm{i}, \mathrm{t}}=$ accounting earnings adjusted by market value of company $i$ in period $t$;

$\mathrm{SC}_{\mathrm{i}, \mathrm{t}}=$ independent variables representing the structural and compositional characteristics of the board of company $i$ in period $t$, including SB (size of the board - represented by the number of effective members as stated in the AR or RF), IND (board independence - represented by the ratio of the number of independent directors to the total number of directors in the company (\%). Independent directors are identified as those who are classified by companies as such in their AR and RF), or CCEO(separation of roles of chairman of the board of directors and executive director/CEO - a dummy varia- ble that assumes a value of 1 when the roles of chairman and executive director are separated. This information is obtained through analysis of the AR or RF);

$\mathrm{NEG}_{\mathrm{i}, \mathrm{t}}=$ dummy variable for companies that have losses in the period;

$\mathrm{S}_{\mathrm{i}, \mathrm{t}}$ and $\mathrm{Y}_{\mathrm{i}, \mathrm{t}}=$ dummy variables for sector and year, respectively, which are included with the intention of eliminating macroeconomic events that may influence the return-earnings relation;

$\xi_{\mathrm{i}, \mathrm{t}}=$ error term of company $i$ in period $t$.

Following the methodology of Sarlo Neto (2009), the parameter of interest is $\beta_{2}$, which represents the strength of the relationship between stock returns $\left(\mathrm{SR}_{\mathrm{i}, \mathrm{t}}\right)$ and accounting information $\left(\mathrm{AE}_{\mathrm{i}, \mathrm{t}}\right)$ - informativeness, controlled by the board structure variable $\left(\mathrm{SC}_{\mathrm{i}, \mathrm{t}}\right)$. If $\beta_{2}$ is positive and significant, it indicates that the board structure variables provide increased informativeness; if negative, it suggests reduced informativeness.

\section{ANALYSIS AND DISCUSSION OF RESULTS}

Descriptive statistics are presented in Table 2. A high dispersion of the data can be observed, in particular for the variables accounting earnings, equity, and market-to-book ratio. The high standard deviations from the mean demonstrate the heterogeneity of the sample. The size variable has the lowest standard deviation and there is no significant difference between the mean and the median.
The analysis of the qualitative variables reveals that during the study period, $21.56 \%$ of the sample, i.e., 146 observations, correspond to companies who experienced a loss in the fiscal year. Regarding the CCEO variable, in $72.87 \%$ of cases, i.e., in 494 observations, there is a separation of the roles of chairman of the board and executive director/CEO.

Table 2

Descriptive statistics

\begin{tabular}{|c|c|c|c|c|c|c|}
\hline Variable & $\mathrm{N}^{0}$ of obs. & Mean & Median & Standard Deviation & Minimum & Maximum \\
\hline SR & 678 & 0.1715 & 0.0425 & 0.6914 & -1.3003 & 5.4115 \\
\hline $\mathrm{P}$ & 678 & 1.2693 & 1.0787 & 0.8716 & 0.0007 & 7.2154 \\
\hline $\mathrm{AE}$ & 678 & 0.0469 & 0.0619 & 0.18864 & -1.2633 & 0.8048 \\
\hline SIZ & 678 & 14.1930 & 14.2781 & 1.7987 & 10.2989 & 17.8499 \\
\hline IDB & 678 & 0.6285 & 0.5815 & 0.3405 & 0.1345 & 2.2761 \\
\hline MTB & 678 & 2.2061 & 1.4980 & 3.0916 & -4.1724 & 15.5072 \\
\hline SB & 678 & 7.436578 & 7 & 2.59723 & 3 & 17 \\
\hline IND & 678 & 0.1869 & 0.1667 & 0.2012 & 0 & 0.8333 \\
\hline
\end{tabular}

Table 3 shows the correlations between the model variables. The dependent variable price has a positive and significant correlation with the AE, EQ, SIZ, and MTB variables. The two variables representing board structure (SB and IND) and IDB do not have a statistically significant correlation with $\mathrm{P}$. The calculated correlations should therefore not be considered negative for IDB and SB and positive for IND, as these showed no statistical significance, that is, correlations different from zero. The non-signi- ficance of the correlations between these variables could be a consequence of the reduced number of observations in the sample, which is a common difficulty in studies in the Brazilian context due to the small number of companies with securities traded on the exchange. The statistical non-significance of the correlations does not affect the subsequent analysis, however, because the correlations do not represent causal effects, i.e., effects that may be identified by means of multiple regressions.

Table 3

Pearson correlations between variables

\begin{tabular}{|c|c|c|c|c|c|c|c|c|c|}
\hline Variable & SR & $\mathbf{P}$ & $\mathrm{AE}$ & EQ & IDB & SIZ & МTB & IND & SB \\
\hline $\mathrm{AE}$ & $0.269 *$ & $0.258^{*}$ & 1.00 & & & & & & \\
\hline EQ & - & $0.294^{*}$ & $0.380 *$ & 1.00 & & & & & \\
\hline IDB & - & -0.035 & $-0.392 *$ & $-0.502 *$ & 1.00 & & & & \\
\hline MTB & - & $0.158 *$ & 0.047 & $-0.155^{*}$ & $-0.100 *$ & $0.302 *$ & 1.00 & & \\
\hline IND & $0.069^{* * *}$ & 0.062 & 0.052 & 0.061 & $-0.207^{*}$ & $0.123^{*}$ & $0.098^{* *}$ & 1.00 & \\
\hline SB & 0.000 & -0.000 & $0.180 *$ & $0.174^{*}$ & - 0.196* & $0.493^{*}$ & 0.027 & 0.037 & 1.00 \\
\hline
\end{tabular}

Note: $* * *$, and $* * *$ represent significance levels of $1 \%, 5 \%$, and $10 \%$, respectively. 
The dependent variable abnormal return only lacked a statistically significant correlation with board size. Visual analysis of the data reveals that there are no correlations between pairs of variables above 0.60 . The highest correlations are observed between EQ and IDB (-0.502) and between SIZ and SB (0.493), both significant at $1 \%$.

Table 4 shows the results obtained for the accounting information relevance model. Model 1, reported in the second column of Table 4, uses board size as the board structure variable. The results show that the $\delta 3$ and $\delta 4$ coefficients are both statistically significant, indicating that in terms of accounting information relevance in the Brazilian market, board size is not a determining variable. These findings corroborate those of Alkdai and Hanefah (2012), who concluded that board size is not an important influencing factor of accounting information relevance given the statistical non-significance of the coefficients.

The third column of Table 4 shows the results of the accounting information relevance model associated with board independence. The results show that the $\delta 3$ and $\delta 4$ coefficients are both positive. $\delta 3$ ( $\left.\mathrm{AE}{ }^{*} \mathrm{IND}\right)$ is not statistically significant, but $\delta 4$ (EQ ${ }^{*}$ IND) has statistical significance.

In the studies by Alkdai and Hanefah (2012) and Habib and Azim (2008), it was not possible to confirm a positive effect of board independence on accounting information relevance due to the statistical non-significance of the coefficients.
For the Brazilian market, the results show a positive effect of board independence for the equity variable but not for the net earnings variable. According to Lopes (2001),for the Brazilian market, it is expected that the relevance would be greater for equity than for net income given Brazil's governance structures and capital market.

The results suggest that accounting information relevance is greater for companies with more independent boards, most likely because they develop their monitoring functions with greater efficiency, as argued by Jensen (1993), Beasley (1996), Beekes, Pope, and Young (2004), and Lopes and Walker (2008).

The results of the accounting information relevance model in association with the separation of the roles of chairman and executive director are shown in the last column of Table 4 . The $\delta 4$ coefficient (EQ ${ }^{*}$ IND) is statistically significant and has a positive sign; therefore, the relevance of accounting information may be increased in the case of equity. However, given the statistical non-significance of the $\mathrm{AE}^{\star} \mathrm{CCEO}$ coefficients, it is not possible to confirm the effect of separating the roles of chairman and executive director for the case of accounting earnings.

The results for the relevance model indicate a positive effect on equity for board independence and separation of the chairman and executive director roles, reinforcing Lopes' (2001) argument that EQ in the Brazilian market has greater relevance.

Table 4 Results for the relevance model

\begin{tabular}{c} 
Stock price as dependent variable \\
\hline$P_{i, t}=\delta_{0}+\delta_{1} A E_{i, t}+\delta_{2} E Q_{i, t}+\delta_{3} A E_{i, t} * S C_{j, i, t}+\delta_{4} E Q_{i, t} * S C_{j, i, t}+\delta_{5} I D B_{i, t}+\delta_{6} M T B_{i, t}+\delta_{7} S I Z_{i, t}+\xi_{i, t}$
\end{tabular}

Panel A: Variable statistics

\begin{tabular}{|c|c|c|c|c|c|c|}
\hline \multirow[b]{2}{*}{ Variables } & \multicolumn{2}{|c|}{$\begin{array}{c}\text { Model } 1 \text { - Hypothesis: 1a } \\
\text { SC }=\text { SB }\end{array}$} & \multicolumn{2}{|c|}{$\begin{array}{c}\text { Model } 2 \text { - Hypothesis: 2a } \\
\text { SC = IND }\end{array}$} & \multicolumn{2}{|c|}{$\begin{array}{c}\text { Model } 3 \text { - Hypothesis: 3a } \\
\text { SC = CCEO }\end{array}$} \\
\hline & Coef. & RSE & Coef. & RSE & Coef. & RSE \\
\hline Intercept & -0.300 & 0.333 & -0.189 & 0.284 & -0.17 & 0.296 \\
\hline $\mathrm{AE}$ & 0.836 & 0.816 & 0.620 & 0.387 & $1.236^{* *}$ & 0.514 \\
\hline EQ & $0.486^{*}$ & 0.171 & $0.338^{*}$ & 0.076 & $0.309^{*}$ & 0.091 \\
\hline $\mathrm{AE} * \mathrm{SC}$ & 0.004 & 0.108 & 2.239 & 1.635 & -0.560 & 0.531 \\
\hline $\mathrm{EQ} * \mathrm{SC}$ & -0.007 & 0.019 & $0.578^{* *}$ & 0.243 & $0.217^{* *}$ & 0.091 \\
\hline IDB & $0.758^{*}$ & 0.165 & $0.687^{*}$ & 0.157 & $0.745^{*}$ & 0.153 \\
\hline MTB & 0.059* & 0.018 & $0.059^{*}$ & 0.017 & $0.062^{*}$ & 0.017 \\
\hline SIZ & $0.042^{* * *}$ & 0.022 & $0.036^{* * *}$ & 0.019 & 0.032 & 0.020 \\
\hline
\end{tabular}

Panel B: Model statistics

\begin{tabular}{|c|c|c|c|}
\hline $\mathrm{R}^{2}$ Adjust. & $19.84 \%$ & $23.37 \%$ & $21.08 \%$ \\
\hline F stat. & 15.36 & 18.74 & 15.75 \\
\hline Prob. F & 0.000 & 0.000 & 0.000 \\
\hline$N^{\circ}$ Obs. & 678 & 678 & 678 \\
\hline
\end{tabular}

Note: Coef. is the estimated coefficient. RSE is the robust standard error. ${ }^{*}, * *$, and ${ }^{* * *}$ represent significance levels of $1 \%$, $5 \%$, and $10 \%$, respectively. All of the models were adjusted for White's robust errors, making them consistent for heteroscedasticity. Panel data approach: POLS model. SB is the size of the board, represented by the number of permanent members. IND is the percentage of board independence, represented by dividing the number of independent directors by the total number of board members. CCEO is a binary variable that takes the value 1 (one) if the positions of chairman of the board and executive director are held by different people and 0 (zero) in all other cases.

The results for the earnings informativeness model are reported in two tables: Table 5 contains the results for the variables related to board size, and Table 6 shows the results for the board independence and separation of roles variables.
The $\beta 2$ coefficient $\left(\mathrm{AE}{ }^{*} \mathrm{SB}\right)$ for Model 1 , shown in the second column of Table 5, exhibits a negative sign but is not statistically significant. The hypothesis that earnings informativeness is negatively related to board size therefore cannot be accepted. Vafeas (2000) argues 
that smaller boards (represented by the first quartile) have a positive relationship and larger boards (represented by the fourth quartile) have a negative relationship with earnings informativeness. Thus, Model 2, reported in the third column of Table 5, was operationalized to assess whether such a relationship exists for the Brazilian market. The SB variable was replaced by two dummy variables representing the first and fourth quartiles of board size.

The estimated coefficient of $\mathrm{AE}^{\star} \mathrm{SB} 1$ has a positive sign, as suggested by Vafeas(2000), although it is not statistically significant, i.e., it is not possible to say that the effect is different from zero. For the $\mathrm{AE}^{\star} \mathrm{SB} 4$ variable, the sign of the estimated coefficient is negative and statistically significant at $10 \%$, as suggested by Vafeas (2000), indicating that companies with larger boards have less informative earnings relative to other companies. This result partially corroborates the study by Alves (2011), who also finds a relationship between larger board sizes and greater earnings management.

Table $5 \quad$ Results for the informativeness model - board size

\begin{tabular}{|c|c|c|c|c|c|c|}
\hline \multicolumn{7}{|c|}{ Abnormal return as dependent variable } \\
\hline \multicolumn{7}{|c|}{$S R_{i, t}=\beta_{0}+\beta_{1} A E_{i, t}+\beta_{2} A E * S C_{j \dot{j}, t}+\beta_{3} A E^{*} N E G_{i, t}+\sum_{s=2}^{19} \phi_{s} S_{i, t}+\sum_{A=2}^{4} \delta_{A} Y_{i, t}+\xi_{i, t}$} \\
\hline \multicolumn{7}{|c|}{ Panel A: Variable statistics } \\
\hline \multirow[b]{2}{*}{ Variables } & \multicolumn{2}{|c|}{$\begin{array}{l}\text { Model } 1 \text { - Hypothesis } 1 \mathrm{~b} \\
\qquad \mathrm{SC}=\mathrm{SB}\end{array}$} & \multicolumn{2}{|c|}{$\begin{array}{l}\text { Model } 2-\text { Hypothesis } 1 \mathrm{~b} \\
\text { SC }=\text { SB1 and SB4 }\end{array}$} & \multicolumn{2}{|c|}{$\begin{array}{l}\text { Model } 3 \text { - Hypothesis } 1 \mathrm{C} \\
\qquad \text { SC }=\text { DIBGC }\end{array}$} \\
\hline & Coef. & RSE & Coef. & RSE & Coef. & RSE \\
\hline Intercept & $-0.495^{*}$ & 0.166 & $-0.476^{*}$ & 0.167 & $-0.482^{*}$ & 0.169 \\
\hline $\mathrm{AE}$ & $2.885^{*}$ & 0.998 & $2.185^{*}$ & 0.565 & $1.988^{*}$ & 0.552 \\
\hline$A E * S C$ & -0.108 & 0.079 & - & - & 0.126 & 0.269 \\
\hline $\mathrm{AE} * \mathrm{SC} 1$ & - & - & 0.311 & 0.490 & - & - \\
\hline $\mathrm{AE}^{*} \mathrm{SC} 4$ & - & - & $-0.887^{* * *}$ & 0.529 & - & - \\
\hline AE*NEG & $-2.218^{*}$ & 0.761 & $-2.213^{*}$ & 0.763 & $-1.921^{*}$ & 0.621 \\
\hline Dummy Year & Yes & & Yes & & Yes & \\
\hline Dummy Sector & Yes & & Yes & & Yes & \\
\hline \multicolumn{7}{|c|}{ Panel B: Model statistics } \\
\hline $\mathrm{R}^{2}$ Adjust. & $22.53 \%$ & & $22.82 \%$ & & $22.09 \%$ & \\
\hline F stat. & 5.06 & & 5.06 & & 5.17 & \\
\hline Prob. F & 0.000 & & 0.000 & & 0.000 & \\
\hline$N^{\circ}$ Obs. & 678 & & 678 & & 678 & \\
\hline
\end{tabular}

Note: Coef. is the estimated coefficient. RSE is the robust standard error. ${ }^{*}, * *$, and ${ }^{* * *}$ represent significance levels of $1 \%, 5 \%$, and $10 \%$, respectively. For the dummy variables year and sector, yes means that at least one was statistically significant, and no means the opposite. All of the models were adjusted for White's robust errors, making them consistent for heteroscedasticity. Panel data approach: POLS model. SB is board size, represented by the number of permanent members on the board. SB1 is a binary variable that takes the value 1 (one) if the board size is equal to or less than the first quartile and 0 (zero) in all other cases. SB4 is a binary variable that takes the value 1 (one) if the board size is equal to or greater than the fourth quartile and 0 (zero) in all other cases. DIBGC is a binary variable that takes the value 1 (one) if the board size is 5-11 members and 0 (zero) in all other cases.

The results for Model 3 are reported in the last column of Table 5 and test the hypothesis that earnings informativeness is increased for companies that have an intermediate number of directors. The $\beta 2$ coefficient shows a positive sign, as expected, but the result is statistically not significant, thus precluding acceptance of Hypothesis H1c. This result indicates that for the Brazilian market, earnings informativeness is not higher for boards with an intermediate number of sitting members.

Compared with previous studies, the results of this study are similar to those of Vafeas (2000) when the sample is divided according to quartiles, indicating that larger boards reduce the informativeness of reported financial earnings.

However, when considering board size in a linear fashion, the results agree with those of Asteriou and Dimitropoulos (2010), who also did not find statistical significance for the accounting earnings variable conditioned on board size. However, the results contrast with those obtained by Ahmed et al. (2006) because those authors obtained empirical evidence to support the hypothesis that an increase in board size reduces earnings informativeness.

The second column of Table 6 shows the results for Model 1, which uses the IND variable to represent the percentage of board independence. The $\beta_{2}(\mathrm{AE} *$ IND) coefficient has a positive sign, as expected, and is statistically significant at $10 \%$, confirming the hypothesis that greater board independence increases the informativeness of accounting earnings. 
Alternatively, as suggested by Fama and Jensen (1983), a dummy was created for board independence to identify boards dominated by independent directors to test whether such boards are more effective. The results for Model 2 of Table 6, which uses the DOM variable as a proxy for board independence, are reported in the third column of Table 6 . The $\beta_{2}\left(\mathrm{AE}{ }^{*} \mathrm{DOM}\right)$ coefficient is positive and statistically significant at $10 \%$. This result reinforces the results obtained in Model 1 of Table 6, which indicate that earnings informativeness increases with greater board independence.

\section{Table 6 Results for the informativeness model.}

Abnormal return as dependent variable

$$
S R_{i, t}=\beta_{0}+\beta_{1} A E_{i, t}+\beta_{2} A E * S C_{j i, t}+\beta_{3} A E * N E G_{i, t}+\sum_{s=2}^{19} \phi_{s} S_{i, t}+\sum_{A=2}^{4} \delta_{A} Y_{i, t}+\xi_{i, t}
$$

Panel A: Variable statistics

\begin{tabular}{|c|c|c|c|c|c|c|}
\hline \multirow[b]{2}{*}{ Variables } & \multicolumn{2}{|c|}{$\begin{array}{c}\text { Model } 1-\text { Hypothesis 2a } \\
\text { SC }=\text { IND }\end{array}$} & \multicolumn{2}{|c|}{$\begin{array}{c}\text { Model } 2-\text { Hypothesis } 2 \mathrm{a} \\
\text { SC }=\text { DOM }\end{array}$} & \multicolumn{2}{|c|}{$\begin{array}{c}\text { Model } 3 \text { - Hypothesis } 3 \text { a } \\
\text { SC }=\text { CCEO }\end{array}$} \\
\hline & Coef. & RSE & Coef. & RSE & Coef. & RSE \\
\hline Intercept & $-0.456^{*}$ & 0.165 & $-0.486^{*}$ & 0.166 & $-0.494^{*}$ & 0.166 \\
\hline $\mathrm{AE}$ & $1.884^{*}$ & 0.594 & $2.037^{*}$ & 0.560 & $2.243^{*}$ & 0.716 \\
\hline$A E * S C$ & $1.767^{* * *}$ & 1.053 & $2.365^{* * *}$ & 1.322 & -0.214 & 0.395 \\
\hline$A E * N E G$ & $-1.932^{*}$ & 0.634 & $-1.931^{*}$ & 0.627 & $-2.011^{*}$ & 0.668 \\
\hline Dummy year & Yes & & Yes & & Yes & \\
\hline Dummy sector & Yes & & Yes & & Yes & \\
\hline \multicolumn{7}{|c|}{ Panel B: Model statistics } \\
\hline $\mathrm{R}^{2}$ Adjust. & $22.72 \%$ & & $23.09 \%$ & & $22.15 \%$ & \\
\hline Prob. F & 0.000 & & 0.000 & & 0.000 & \\
\hline No Obs. & 678 & & 678 & & 678 & \\
\hline
\end{tabular}

Note: Coef. is the estimated coefficient. RSE is the robust standard error. *, **, and *** represent significance levels of $1 \%, 5 \%$, and $10 \%$, respectively. For the dummy variables year and sector, yes means that at least one was statistically significant, and no means the opposite. All of the models were adjusted for White's robust errors, making them consistent for heteroscedasticity. Panel data approach: POLS model. IND is the percentage of board independence, represented by dividing the number of independent directors by the total number of directors. DOM is a binary variable that takes the value 1 (one) if the percentage of independence is over $50 \%$ and 0 (zero) in other cases. CCEO is a binary variable that takes the value 1 (one) if the roles of chairman and executive director are held by different people and 0 (zero) in other cases.

The findings from this study corroborate the results of the studies by Firth et al. (2007), Dimitropoulos and Asteriou (2010), and Abdoli and Royaee (2012), who also find evidence that earnings informativeness increases as the proportion of independent directors increases. Moreover, the results reinforce the arguments of Beasley (1996) and Jensen (1993) that more independent boards are more effective, and Lopes and Walker's (2008) argument that an independent board is perceived by the market as a positive sign that a company is committed to behaving according to basic rules of good conduct.

The H3b study hypothesis states that earnings informativeness is greater in companies where there is a separation of the roles of chairman of the board and executive director/CEO. The F statistic (5.20) of Model 1 expressed in Table 6 confirms the significance of the model at the $1 \%$ level. The results reported in Model 3 presented in the last column of Table 6 show a $\beta 2\left(\mathrm{AE}^{\star} \mathrm{CCEO}\right)$ coefficient with a negative sign and that is not statistically significant. The study's hypothesis predicted that the relationship between the separation of roles and earnings informativeness would be positive. However, the results show a negative relationship without a statistically significant coefficient.
Therefore, we cannot say in this case that the relationship is non-zero, i.e., that there is some effect.

A negative relationship between the separation of roles and accounting earnings informativenessis also identified by Abdoli and Royaee (2012), indicating greater informativeness in companies where the chairman is also the executive director. This result is explained by the authors as the market perceiving the accumulation of functions as a positive factor in a company's management.

The results obtained in this study corroborate those of Lopes and Walker (2008) and Gabriel (2011), indicating that the quality of financial information is greater in companies with better corporate governance practices, but differ from the results of Antunes et al. (2009), who claim that different levels of the BM\&FBovespa did not affect the quality of earnings. However, comparisons with these results should be analyzed with caution because in the studies cited, the proxies for governance were indices or listings on different stock exchange levels, which are different measures from those used in this study.

Table 7 shows a summary of the results according to the study hypotheses formulated in Section 2.5. 
Summary of results for the study hypotheses

\begin{tabular}{c|c|c|c}
\hline Hypothesis & Expected sign & Sign obtained & Statistically significant \\
\hline $\mathrm{H} 1 \mathrm{a}$ & - & Mixed & No \\
\hline $\mathrm{H} 1 \mathrm{~b}$ & - & - & Only one specification \\
\hline $\mathrm{H} 1 \mathrm{c}$ & + & + & No \\
\hline $\mathrm{H} 2 \mathrm{a}$ & + & + & Equity \\
\hline $\mathrm{H} 2 \mathrm{~b}$ & + & Mixed $(+$ EQ and $-\mathrm{AE})$ & Yes confirmed \\
\hline $\mathrm{H} 3 \mathrm{a}$ & + & - & Equity \\
\hline $\mathrm{H} 3 \mathrm{~b}$ & + & Confirmed & Confirmed \\
\hline
\end{tabular}

In summary, the results reveal that for companies that trade stocks on the BM\&FBovespa in the Brazilian market, the characteristics of board independence and separation of the chairman and executive director/CEO roles positively influence the quality of reported accounting information, specifically regarding the relevance of equity, upon which both showed a positive effect. In addition, board independence and board size influence the quality of accounting information, specifically regarding reported earnings informativeness: board independence showed a positive effect and board size a negative effect.

\section{FINAL CONSIDERATIONS}

The aim of this study was to investigate the effects of board characteristics (size, independence, and separation of the roles of chairman and executive director/CEO) on accounting information relevance and earnings informativeness of companies listed on the BM\&FBovespa.

The empirical evidence was obtained using the multivariate multiple regression technique based on a data sample ofnon-financial companies with annual stock market liquidity above 0.001 for the period from 20082011 and that represented 19 sectors of the economy according to the Economática application classification.

The empirical evidence obtained from the Brazilian market, based on the study sample, allows acceptance of the hypotheses that board independence ( $\mathrm{H} 2 \mathrm{a})$ and separation of the roles of chairman and executive director/CEO (H3a) have positive effects on the relevance of equity.

The hypothesis that board independence positively influences the informativeness of reported earnings (H2b) cannot be rejected, indicating that earnings informativeness is greater in companies with more independent boards of directors.

The hypothesis that board size negatively influences reported accounting earnings informativeness ( $\mathrm{H} 1 \mathrm{~b}$ ) cannot be rejected when considering the larger boards represented by the fourth quartile, indicating that companies with larger boards have reduced reported accounting earnings informativeness.

The hypotheses that earnings informativeness is greater for companies that follow IBGC recommendations as to the ideal number of members (H1c) and that earnings informativeness is greater in companies where there is separation of the roles of chairman and executive director (H3b) are not accepted because the coefficients are not statistically significant.

The results do not uphold the hypothesis that board size has an effect on accounting information relevance (H1a) because the coefficients are not statistically significant.

The limitations of this study relate to the characteristics of the Brazilian stock market, which includes companies with low liquidity and a small number of participants compared with other markets, such as in the United States. This factor limits the sample size. In addition, the measure of board independence used in the study may be distorted because the classification of a director as independent was made by the company itself, and the definition of independence may therefore have varied between companies.

In concluding this study, it should be noted that there are still gaps in the national literature regarding other characteristics of the board of directors that may be investigated in the future. These include: i) investigating the relationship between two-tier boards, formed by the board of directors and a permanent audit committee, and specific properties of the quality of accounting information; ii) investigating the relationship between specific properties of the quality of accounting information (relevance, faithful representation, and timeliness) and audit committees in the Brazilian environment; and iii) investigating whether, for the Brazilian market, the financial expertise of members of boards of directors and audit committees affect the quality of reported accounting information. 


\section{References}

Abdoli, M. R., \&Royaee, R. (2012). Board monitoring and earnings quality: an empirical study in Iran. African Journal of Business Management, 6 (11), 4179-4184.

Adams, R. B., Hermalin, B. E., \&Weisbach, M. S. (2010). The role of boards of directors in corporate governance: a conceptual framework \& survey. Journal of Economic Literature, 48 (1), 58-107.

Ahmed, A. S., \& Duellman, S. (2007). Accounting conservatism and board of director characteristics: an empirical analysis. Journal of Accounting and Economics, 43 (2-3), 411-437.

Ahmed, K., Hossain, M., \& Adams, M. B. (2006).The effects of board composition and board size on the informativeness of annual accounting earnings. Corporate Governance, 14 (5), 418-431.

Alkdai, H. K. H., \&Hanefah, M. M. (2012).Board of directors' characteristics and value relevance of accounting information in Malaysian shariah-compliant companies: a panel data analysis. Economics and Finance Review, 2 (6), 31-44.

Alves, S. M. G. (2011). The effect of the board structure on earnings management: evidence from Portugal. Journal of Financial Reporting \& Accounting, 9 (2), 141-160.

Anderson, R: C., Mansi, S., \& Reeb, D. M. (2004). Board characteristics, accounting report integrity, and the cost of debt. Journal of Accounting \& Economics (JAE), 37 (3), 315-342.

Antunes, ,G. A., Teixeira, A. J. C., Costa, F. M., \& Nossa, V. (2009). Efeitos da adesão aos níveis de governança da Bolsa de Valores de São Paulo na qualidade da informação contábil. Advances in Scientific and Applied Accounting,3 (1), 1-14.

Ball, R., \& Brown, P. (1968). An empirical evaluation of accounting income numbers. Journal of Accounting Research, 6 (2), 159-178.

Barth, M. E., Beaver, W. H., \& Landsman, W. R. (2001). The relevance of the value relevance literature for accounting standard setting: another view. Journal of Accounting \& Economics, 31 (1-3), 77-104.

Beasley, M. (1996).An empirical analysis between the board of director composition and financial statement fraud. The Accounting Review, 71 (4), 443-466.

Beaver, W. (1968). The information content of annual earnings , announcements. Journal of Accounting Research, 6, 67-92.

Beekes, W., Pope, P., \& Young, S. (2004). The link between earnings timeliness, earnings conservatism and board composition: evidence from the UK. Corporate Governance, 12 (1), 47-59.

Bratton, W. W., \&Mccahery, J. A. (1999). Comparative corporate governance and the theory of the firm: the case against global cross reference. Columbia Journal of Transnational Law, 38 (2), 214-297.

Brown, L., \&Caylor, M. (2006).Corporate governance and firm valuation. Journal of Accounting and Public Policy, 25 (4), 409-434.

Brown, W. D., He, H., \&Teitel, K. (2006).Conditional conservatism and the value relevance of accounting earnings: an international study. European Accounting Review, 15 (4), 605-626.

Bushman, R. M.,\&Smith.A. J. (2001). Financial accounting information and corporate governance. Journal of Accounting and Economics, 31 (1-3),237-333.

Dimitropoulos, P., \&Asteriou, D. (2010). The effect of board composition on the informativeness and quality of annual earnings: empirical evidence from Greece. Research in International Business and Finance,24 (2), 190-205

Fama, E. F., \& Jensen, M. C. (1983).Separation of ownership and control. Journal of Law and Economics, 26 (2), 301-325.

Firth, M., Fung, P. M.Y., \& Rui, O. M. (2007). Ownership, two-tier board structure, and the informativeness of earnings - evidence from China Journal of Accounting and Public Policy, 26 (4), 463-496.

Gabriel, F. (2011). Impacto da adesão às práticas de governança corporativa no índice de qualidade da informação contábil. Tese de doutorado, Universidade de São Paulo, São Paulo, SP, Brasil

Gillan, S.L. (2006). Recent developments in corporate governance: an overview. Journal of Corporate Finance, 12 (3), 381-402.

Gul, F. A., \& Leung, S. (2004). Board leadership, outside directors expertise and voluntary corporate disclosures. Jourrial of Accounting and Public Policy, 23 (5), 351-379.

Habib, A., \&Azim, I. (2008). Corporate governance and the valuerelevance of accounting information: Evidence from Australia. Accounting Research Journal, 21 (2), 167-194.

Hermalin, B., \&Weisbach, M. S. (2003). Boards of directors as an endogenously determined institution: a survey of the economic. literature. Economic Policy Review of the Federal Reserv Bank of New. York,9 (1), 7-36.

Instituto Brasileiro de Governança Corporativa. IBGC. (2009).Código das melhores práticas de governança corporativa. (4 ed.). São Paulo, SP: IBGC.

Jensen, M.C. (1993). The modern industrial revolution, exit and the failure of internal control systems. Journal of Finance, 48 (3), 831-880.

Jensen, M. C., \& Meckling, W. (1976). Theory of the firm: managerial behavior, agency cost, and ownership structure. Journal of Financial Economics, 3 (4), 305-360.

Kothari, S.P., \& Zimmerman J. L. (1995).Price and return models. Journal of Accounting and Economics, 20 (2), 155-192.

La Porta, R., Lopez-De-Silanes, F, Shleifer, A., \&Vishny, R. (2000). Investor protection and corporate governance. Journal of Financial Economics, 58 (1-2), 3-27.

Lara, J. M. G., Osma, B. G., \& Penalva, F. (2007). Board of directors' characteristics and conditional accounting conservatism: Spanish evidence. European Accounting Review, 16 (4), 727-755.

Lei 6.404, de 15 de dezembro de 1976. (1976). Dispóe sobre as Sociedades por Ações. Recuperado em 19 outubro, 2012, de http://www.planalto. gov.br/ccivil_03/leis/16404consol.htm.

Lipton, M., \&Lorsch, J. (1992).A modest proposal for improved corporate governance. Business Lawyer, 48 (1), 59-77.

Lopes, A: B. (2001). Uma contribuição ao estudo da relevância da informação contábil para o mercado de capitais: o modelo de Ohlson aplicado à BOVESPA. Tese de doutorado, Universidade de São Paulo São Paulo, SP, Brasil.

Lopes, A. B. (2002). A informação contábil e o mercado de capitais. São Paulo: Pioneira Thomson Learning:

Lopes, A. B. (2008). A teoria dos contratos, governança corporativa e contabilidade. In S. Iudícibus, \& A. B. Lopes (Coord.). Teoria avançada da contabilidade. (pp. 170-185). São Paulo: Atlas.

Lopes, A. B., \& Martins, E. (2005). Teoria da contabilidade: uma nova abordagem. São Paulo: Atlas.

Lopes, A. B., \& Walker, M. (2008).Firm-level incentives and the informativeness of accounting reports: an experiment in Brazil. Recuperado em 22 de novembro de 2012, de http://ssrn.com/ abstract=1095781 ou http://dx.doi.org/10.2139/ssrn.1095781.

Marra A., Mazzola, P., \&Prencipe, A. (2011). Board monitoring and earnings management pre- and post-IFRS: The International Journal of Accounting, 46 (2), 205-230.

Moreira, R. L., Colauto, R. D., \&Amaral, H. F. (2010).Conservadorismo condicional: estudo a partir de variáveis econômicas. Revista Contabilidade \& Finanças, 21 (54), 64-84.

Sarlo Neto, A. (2009). Relação entre a estrutura de propriedade e a informatividade dos lucros contábeis no mercado brasileiro. Tese de doutorado, Universidade de São Paulo, São Paulo, SP, Brasil.

Vafeas, N: (2000). Board structure and the informativeness of earnings. Journal of Accounting and Public Policy, 19 (2), 139-160.

Xie, B., Davidson, W: N., \&Dadalt, P. J. (2003). Earnings management and corporate governance: the role of the board and the audit committee. Journal of Corporate Finance, 9 (3), 295-316.

Yermack, D. (1996). Higher market valuation of companies with a small board of directors. Journal of Financial Ećnomics, 40 (2), 185-213. 